\title{
Complications and risk factors in transrectal ultrasound-guided prostate biopsies
}

\author{
Hospital das Clínicas, Faculdade de Medicina de Botucatu (Unesp), \\ Botucatu, São Paulo, Brazil
}

CONTEXT AND OBJECTIVE: Prostate biopsy is not a procedure without risk. There is concern about major complications and which antibiotics are best for routine use before these biopsies. The objective was to determine the rate of complications and the possible risk factors in prostate biopsies.

DESIGN AND SETTING: Prospective study, Faculdade de Medicina de Botucatu.

METHODS: Transrectal ultrasound (TRUS) guided prostate biopsies were carried out in 174 patients presenting either abnormality in digital rectal examinations (DRE) or levels higher than $4 \mathrm{ng} / \mathrm{ml}$ in prostate-specific antigen (PSA) tests, or both.

RESULTS: Hemorrhagic complications were the most common $(75.3 \%)$, while infectious complications occurred in $19 \%$ of the cases. Hematuria was the most frequent type (56\%). Urinary tract infection (UTI) occurred in 16 patients (9.2\%). Sepsis was observed in three patients $(1.7 \%)$. The presence of an indwelling catheter was a risk factor for infectious complications $(\mathrm{p}<0.05)$. Higher numbers of biopsies correlated with hematuria, rectal bleeding and infectious complications $(p<0.05)$. The other conditions investigated did not correlate with postbiopsy complications.

CONCLUSIONS: Post-biopsy complications were mostly self-limiting. The rate of major complications was low, thus showing that TRUS guided prostate biopsy was safe and effective. Higher numbers of fragments taken in biopsies correlated with hematuria, rectal bleeding and infectious complications. An indwelling catheter represented a risk factor for infectious complications. The use of aspirin was not an absolute contraindication for TRUS.

KEY WORDS: Needle biopsy. Prostatic neoplasms. Risk factors. Ultrasonography. Prostate.

口BJECTIVE

Our aim was to assess locally the main complications, possible risk factors, outcomes, safety and effectiveness of TRUSguided biopsies.

PATIENTS AND METHDDS

This was a prospective study involving 177 patients who spontaneously sought our urology service from March 2000 to June 2001. During the medical consultation, we registered personal data, clinical history, DRE and PSA values, and possible risk factors for post-biopsy complications, such as urinary tract infection (UTI), systemic arterial hypertension, diabe- tes, indwelling catheter, use of acetylsalicylic acid and prostatitis antecedents.

The criteria for biopsy indication were abnormality in DRE and/or high PSA values, considering $4 \mathrm{ng} / \mathrm{ml}$ to be the maximum limit for normality (Tandem ${ }^{\circledR}$, Hybritech Inc). In cases with signs or symptoms of possible UTI, or a previous positive urine culture, a new urine culture was requested following the appropriate treatment. Such patients were only biopsied after negative urine culture results had been obtained.

The first 106 patients were administered sulfamethoxazole $(800 \mathrm{mg})$ and trimethoprim (160 mg) twice a day, beginning two days before the procedure and continuing for five days afterwards, thus totaling seven days of prophylaxis. The last 71 patients were prescribed short-duration prophylaxis consisting of $500 \mathrm{mg}$ of ciprofloxacin two hours before and eight hours after the procedure. Before the biopsies were taken, all patients underwent rectal clyster.

The biopsies were performed on an outpatient basis by two urologists (C.M.N.J. and L.A.C.). The procedure was guided by Dornier ultrasound equipment, with a 6.5 $\mathrm{MHz}$ multiplanar transrectal probe using the Biopty Gun ${ }^{\circledR}$. Before the biopsies, DRE was performed once more, in an attempt to associate any abnormality with possible alterations in the TRUS image observed. The volume of the prostate was calculated by means of the revolution ellipsoid formula (height $\mathrm{x}$ width $\mathrm{x}$ length $\mathrm{x}$ 0.52) in cubic centimeters. ${ }^{9}$ Sampling was done per sextant, with additional sampling in suspicious areas such as hypoechogenic areas or those with loss of capsular limits. ${ }^{10}$ In prostates larger than $60 \mathrm{~cm}^{3}$ or in cases of repeated biopsy, the number of samples taken was increased. No sedation was applied, or any local periprostatic anesthesia; only lidocaine gel at the moment when the probe was 
introduced. The biopsied fragments were sent separately for histopathological examination, in vials containing formalin.

After one week, all the patients were assessed in accordance with the study protocol, regarding their symptomatology and post-biopsy complications. After one month, the patients were notified about the histopathological results and respective medical decision.

For the statistical analyses of the variables, Goodman's test for associations between two classified qualitative variables was utilized, and also two non-parametric tests: the Mann-Whitney test for two independent groups and Kruskal-Wallis test for more than two groups of independent variables. All analyses were done using a significance level of 5\%.

RESULTS

The mean age of these 177 patients was $68.2 \pm 8.1$ years (range: $47-87$ ). Among them, three were excluded: two patients because of irregular use of prophylactic antibiotic and another one because of concomitant use of another antibiotic due to tonsillitis contracted after the prostate biopsy was taken.

Serum PSA values were determined prior to the biopsies in 158 patients $(90.8 \%)$, and their mean value was $18.5 \mathrm{ng} / \mathrm{ml} \pm 38.7$ (range: $0.2-302 \mathrm{ng} / \mathrm{ml}$ ). The mean volume of the prostate was $47 \mathrm{~cm}^{3} \pm 31.2$ (range: $8-325 \mathrm{~cm}^{3}$ ). The mean number of biopsies was $7.5 \pm 2.6$ (range: $3-17$ ). In patients with prostates with less than 60 grams $(\mathrm{n}=135)$, the mean number of samples per procedure was $7.2 \pm 2.3$. In those with prostates larger than 60 grams $(n=39)$, it was $8.8 \pm 3$. Prostate cancer was diagnosed in 43 patients $(23.7 \%)$.

Table 1 shows the frequencies of possible risk factors for complications in TRUS guided biopsy. Only 36 patients did not present any complication after prostate biopsy (20.7\%). It was found that hemorrhagic complications were the most frequent event in 131 patients (75.3\%), while only 25 cases presented infectious complications (14.4\%) (Table 2). Prostate volume, age, use of acetylsalicylic acid, arterial hypertension, previous history of prostatitis, diabetes mellitus and presence of CAP did not increase the probability of any post-biopsy complication.

Hematuria was the most frequent sign in all complications, corresponding to $56.3 \%$ of the cases. Among the hemorrhagic events, rectal bleeding corresponded to $32.8 \%$ (57 cases) and hemospermia to $21.8 \%$ (38 cases). Urethral bleeding was rare, observed in only one case $(0.4 \%)$. Periprostatic and perineal hematomas were not observed (Table 2).

The rate of major complications was low (1.8\%). Among the major complications, one was hemorrhagic, three were infectious with sepsis and one was urine retention. Except for this latter case, all these patients needed medical intervention with hospitalization $(2.3 \%$ of the total number of patients). The length of hospitalization ranged from two to seven days, with no mortality.

Among the major and most frequent complications, hematuria was a self-limiting component. Only one case out of 98 patients needed medical intervention and hospitalization (1\%). A large majority (74.4\%) presented slight hematuria that ceased after the third day. Only $5.1 \%$ presented hematuria for more than one week.

Rectal bleeding was the second most frequent hemorrhagic complication, occurring in $92 \%$ of the cases during the first two days after the procedure. It was more associated with non-diabetic patients (36.5\%) than with diabetic patients $(11.5 \%)(\mathrm{p}<0.05)$.

Another interesting finding was the incidence of hemospermia. Although only $21.8 \%$ reported it (38 patients), its incidence rose almost fourfold when considering only the patients who reported sexual intercourse during the first month after the biopsy.

It was statistically significant that the average number of samples was higher in patients with hematuria and rectal bleeding than in those who did not present these signs $(p=0.05$ and $p=0.02$, respectively). This was not found in patients with hemospermia, or in the overall data for all hemorrhagic complications ( $\mathrm{p}=0.3$ and $\mathrm{p}=0.61$, respectively).

Infectious complications affected $25 \mathrm{pa}-$ tients (14.4\%). UTI was the most common one $(9.2 \%)$, although it was asymptomatic in $37.5 \%$ of the cases. Escherichia coli was the most common bacterium in eight patients.

Table 1. Risk factors for complications in transrectal ultrasound-guided prostate biopsy in 174 patients

\begin{tabular}{lcc}
\hline Risk factors & Number of patients & $(\%)$ \\
\hline Diabetes mellitus & 26 & 15 \\
Arterial hypertension & 61 & 35.1 \\
Bladder catheter & 23 & 13.2 \\
Use of acetylsalicylic acid & 16 & 9.2 \\
History of prostatitis & 25 & 14.4 \\
Prostate cancer & 43 & 23.7 \\
\hline
\end{tabular}

Table 2. Complications following transrectal ultrasound-guided prostate biopsy in 174 patients

\begin{tabular}{lcc}
\hline Complications & Number & $(\%)$ \\
\hline Hemorrhagic complications & 131 & 75.3 \\
hematuria & 98 & 56.3 \\
rectal bleeding & 57 & 32.3 \\
hematochezia & 25 & 14.4 \\
hemospermia & 38 & 21.8 \\
urethral bleeding & 1 & 0.6 \\
Infectious complications & 25 & 14.4 \\
dysuria & 11 & 6.3 \\
frequency & 7 & 4.0 \\
fever & 11 & 6.3 \\
shivers & 5 & 2.9 \\
positive urine culture & 16 & 9.2 \\
asymptomatic bacteriuria & 6 & 3.4 \\
orchitis & 1 & 0.6 \\
prostatitis & 1 & 0.6 \\
Major complications & 5 & 2.9 \\
sepsis & 3 & 1.7 \\
gross hematuria & 1 & 0.6 \\
urine retention & 1 & 0.6 \\
hospitalization & 4 & 2.3 \\
No complication & 36 & 20.6 \\
\hline
\end{tabular}


There were correlations between infectious complications and the use of indwelling catheters and high numbers of samples $(\mathrm{p}<0.05)$ There was also positive correlation of high numbers of samples with feverish patients $(\mathrm{p}<0.05)$. The other factors studied did not influence the incidence of this kind of complication (Table 3).

\section{DISCUSSION}

Although TRUS-guided prostate biopsy is currently regarded as the ideal method for obtaining prostate fragments for histological analysis, it is considered to be an invasive procedure that is rather uncomfortable for patients. ${ }^{6-8}$ Since most men undergoing biopsy are fit and economically active, there is major interest in making the procedure as safe and effective as possible, thus minimizing complications whenever possible.

Complications also mean higher costs. Kapoor et al. ${ }^{11}$ demonstrated that prophylaxis with ciprofloxacin can reduce post-biopsy costs by 26 dollars per patient, when compared to placebo.

The overall rate of post-biopsy complications was $79.3 \%$. Among these, only $2.9 \%$ were considered major complications, thus

Table 3. Results from statistical tests relating to possible risk factors for complications following transrectal ultrasound-guided prostate biopsy

\begin{tabular}{lcc}
\hline Possible risk factor & Infectious complications & Hemorrhagic complications \\
\hline Age (more than 65 years old) & - & - \\
Diabetes mellitus & - & - \\
Arterial hypertension & - & - \\
Previous prostatitis & - & - \\
Prostate cancer & - & - \\
Number of samples & + & - \\
Prostate volume & - & - \\
Use of acetylsalicylic acid & - & - \\
Bladder catheter & + & - \\
\hline H) negative sign: not significant; (+) positive sign: significant with $p<0.05 .{ }^{*}$ Hematuria and rectal bleeding with $p=0.05$ and \\
$p=0.02$, respectively.
\end{tabular}

attesting that TRUS-guided prostate biopsy is a safe procedure. Most of the minor complications were self-limiting and disappeared a few days after the biopsy, without producing greater morbidity. Such findings have also been reported by other authors like Rodriguez and Terris, ${ }^{6}$ who found at least one complication in $63.6 \%$ of the patients involved in their clinical trial. The importance of our finding is that it indicates that four out of five biopsied men may have some kind of post-biopsy complication. Patients should have access to this information before undergoing the procedure.

Among the most common minor complications, hematuria has been found to be the most frequent one, in 12 to $80 \%$ of biopsied patients. $5,6,8,12-15$ Our data showed that the incidence of hematuria was $56.3 \%$ (98 out of 174 patients). These figures are compatible with the literature, and particularly with studies that were conducted prospectively, with active assessment, either via questionnaires or via interviews (Table 4).

Few cases of hematuria have been reported in retrospective studies in which the focus was not the post-biopsy complications. ${ }^{16}$ Some studies have only considered that cases

Table 4. Complications and risk factors following transrectal ultrasound, as reported in the literature and in the present study

\begin{tabular}{lccccccccc}
\hline Authors & year & $\begin{array}{c}\text { Patient } \\
\text { sample size }\end{array}$ & $\begin{array}{c}\text { Hematuria } \\
(\%)\end{array}$ & $\begin{array}{c}\text { Rectal bleeding } \\
(\%)\end{array}$ & $\begin{array}{c}\text { Hemospermia } \\
(\%)\end{array}$ & $\begin{array}{c}\text { Fever } \\
(\%)\end{array}$ & $\begin{array}{c}\text { Urinary tract } \\
\text { infection (\%) }\end{array}$ & $\begin{array}{c}\text { Sepsis } \\
(\%)\end{array}$ & $\begin{array}{c}\text { Hospitalization } \\
\text { (days) }\end{array}$ \\
\hline Clements et al. ${ }^{5}$ & 1993 & 80 & 20.0 & 9.4 & 5.1 & 2.5 & - & - & 0.004 \\
Aus et al. ${ }^{12}$ & 1996 & 391 & 13.0 & - & & 3.9 & 7.5 & - & - \\
${\text { Rietbergen et al. }{ }^{15}}^{15}$ & 1997 & 1,687 & 49.6 & 2.8 & 45.3 & 4.2 & 7.3 & 0.2 & 0.4 \\
Rodriguez and Terris $^{6}$ & 1998 & 127 & 57.0 & 10.0 & 9.5 & 1.7 & 2.5 & 0 & - \\
Deliveliotis et al. ${ }^{18}$ & 1999 & 120 & 65.0 & 33.3 & 29.1 & 6.6 & 8.1 & 0.16 & 0.16 \\
Raaijmakers et al. ${ }^{14}$ & 2002 & 5,676 & 22.6 & 1.3 & 50.4 & 3.5 & 6.9 & 0.004 & 0.5 \\
Present series & 2004 & 174 & 56.3 & 32.3 & 21.8 & 6.3 & 9.2 & 1.7 & 2.3 \\
\hline
\end{tabular}


less frequent than hemorrhagic ones, although they present higher potential morbidity.

Twenty-five patients (14.4\%) presented at least one type of infectious complication. Post-biopsy UTI was the most frequent single complication among the infectious complications, and was found in $9.2 \%$ of the men (16 out of 174). Six out of these 16 cases of urinary infection (37.5\%) were totally asymptomatic. Asymptomatic bacteriuria was described by Fong et al. ${ }^{19}$ in $7 \%$ of their patients when two types of antibiotics were compared. Ruebush et al. ${ }^{20}$ demonstrated that asymptomatic bacteriuria only occurred in seven patients using placebo $(10.7 \%)$, whereas there were no occurrences in the group that used sulfamethoxazole-trimethoprim. The presence of a positive urine culture is associated with antibiotic prophylaxis, type of antibiotic utilized and presence of UTI before the biopsy. ${ }^{14,21,22}$

Escherichia coli was the most common bacterium, responsible for $50 \%$ of the positive urine cultures ( 8 out of 16). There were no infections caused by anaerobic germs and only one infection caused by Gram-positive germs (coagulase-positive Staphylococcus). If the frequency of hospitalization only among patients with positive urine cultures is considered, it can be seen that its probability is 13 times higher than the hospitalization rate among all the patients involved in our study. Kapoor et al. ${ }^{11}$ reported a similar relationship through observing that one in four of their patients needed hospitalization in cases of asymptomatic bacteriuria, thus demonstrating that this complication must be strongly avoided.

Interruption of the use of thrombolytic agents and medications affecting platelet function is a common practice among surgeons in general and among those who perform prostate biopsies. Such drug suspensions, lasting for seven to ten days, are usually implemented even for patients who need to take these medications, such as coronary patients and those who have suffered ischemic strokes. Since great numbers of patients in these conditions have to undergo prostate biopsies, there is a concern that the suspension of the drug may bring about problems with regard to prevention of thromboembolic phenomena. In one study, the use of acetylsalicylic acid did not increase the incidence of any type of hemorrhagic complications, in spite of the small number of patients. ${ }^{16}$ Similar data were reported by Rodriguez and Terris. ${ }^{6}$

The number of samples taken is also a controversial issue as a risk factor in prostate biopsies. In some studies in the literature, the additional number of biopsies could not be associated with any increase in the numbers of hemorrhagic complications. Naughton et al. compared the morbidity caused by collecting six and twelve fragments in prostate biopsies and found no significant difference. ${ }^{13}$ An additional seventh biopsy did not produce any increase in morbidity according to Raaijmakers et al. ${ }^{14}$

In our study, in spite of not finding any relationship between the number of samples and the total of number of hemorrhagic and hemospermia complications, there was an association between the numbers of samples with hematuria and rectal bleeding. The explanation for this fact is that, with a higher number of samples, the probability of injuring a prostatic and/or rectal blood vessel is higher, thereby causing hematuria and/or rectal bleeding. Higher numbers of samples were not related to hemospermia, which can be explained by the fact that most patients did not report ejaculations following the biopsy. Otherwise, the results might have been similar to those from patients with hematuria and rectal bleeding.

Increased numbers of samples were also correlated with increased rates of infectious complications. The number of samples was a facilitative factor for infections of the urinary tract. One explanation for this is the increasing probability, with each new sampling action, of contamination from the rectal ampulla into the prostate. This contamination would be proportionally smaller when the number of samples was less than or equal to six fragments. The action of multiple sampling may also fa- cilitate the penetration of microorganisms into the bloodstream from a prostate with latent germs, thereby favoring an infectious process. To reinforce this hypothesis, we cite the cases of three patients who developed sepsis and needed hospitalization. These patients had undergone 12,13 and 17 prostate fragmentsampling actions.

Furthermore, when the higher mean number of samples from feverish patients $(9.2 \pm 3.5)$ was compared with the lower number from non-feverish patients $(6.1 \pm 1)$, this difference was statistically significant. Although the number of samples that leads to an increased possibility of infections is not known, an antibiotic with a wide spectrum of action, good prostatic penetration and high urine and serum concentrations should be used when a high number of samples are needed.

Finally, the presence of a bladder catheter (urethral catheter or cystostomy) is an additional risk factor for the occurrence of complications in patients undergoing prostate biopsies. It is believed that the presence of the catheter, as a foreign body in the urinary tract, favors the proliferation of pathogenic microorganisms, even if the urine cultures are negative. Among 23 of our patients with catheters, nine presented infectious complications (39.1\%). Aus et al. ${ }^{12}$ also observed that patients with bladder catheters had 2.3 times more risks of urinary infection than did patients without that risk factor. In our sample of patients, this risk was 3.6 times higher.

\section{CONCLUSIONS}

Post-prostate biopsy complications were mostly self-limiting and did not require medical intervention. The rate of major complications was low, and hence transrectal ultrasound (TRUS) guided prostate biopsy is a safe and effective procedure. However, high numbers of biopsied fragments were correlated with hematuria, rectal bleeding and infectious complications. The use of bladder catheters was also a risk factor for infectious complications. The use of aspirin was not a contraindication for TRUS. 
1. American Cancer Society. Overview: Prostate Cancer. How Many Men Get Prostate Cancer? Available from URL: http://www.cancer. org/docroot/CRI/content/CRI_2_2_1X_How_many_men_get_ prostate_cancer_36.asp?sitearea. Accessed in: 2006 (Jul 31).

2. Rabbani F, Stroumbakis N, Kava BR, Cookson MS, Fair WR. Incidence and clinical significance of false-negative sextant prostate biopsies. J Urol. 1989;159(4):1247-50.

3. Epstein JI, Walsh PC, Sauvageot J, Carter HB. Use of repeat sextant and transition zone biopsies for assessing extent of prostate cancer. J Urol. 1997;158(5):1886-90.

4. Rifkin MD, Alexander AA, Pisarchick J, Matteucci T. Palpable masses in the prostate: superior accuracy of US-guide biopsy compared with accuracy of digitally guided biopsy. Radiology. 1991;179(1):41-2

5. Clements R, Aideyan OU, Griffiths GJ, Peeling WB. Side effects and patient acceptability of transrectal biopsy of the prostate. Clin Radiol. 1993;47(2):125-6.

6. Rodriguez LV, Terris MK. Risks and complications of transrectal ultrasound guided prostate needle biopsy: a prospective study and review of the literature. J Urol. 1998;160(6 Pt 1):2115-20.

7. Irani J, Fournier F, Bon D, Gremmo E, Dore B, Aubert J. Patient tolerance of transrectal ultrasound-guided biopsy of the prostate. Br J Urol. 1997;79(4):608-10.

8. Collins GN, Lloyd SN, Hehir M, McKelvie GB. Multiple transrectal ultrasound-guided prostatic biopsies--true morbidity and patient acceptance. Br J Urol. 1993;71(4):460-3.

9. Lee F, Torp-Pedersen S, Littrup PJ, et al. Hypoechoic lesions of the prostate: clinical relevance of tumor size, digital rectal examination, and prostate-specific antigen. Radiology. 1989;170(1 Pt 1):29-32.
10. Hodge KK, McNeal JE, Terris MK, Stamey TA. Random systematic versus directed ultrasound guided transrectal core biopsies of the prostate. J Urol. 1989;142(1):71-4; discussion 74-5.

11. Kapoor DA, Klimberg IW, Malek GH, et al. Single-dose oral ciprofloxacin versus placebo for prophylaxis during transrectal prostate biopsy. Urology. 1998;52(4):552-8.

12. Aus G, Ahlgren G, Bergdahl S, Hugosson J. Infection after transrectal core biopsies of the prostate--risk factors and antibiotic prophylaxis. Brit J Urol. 1996;77(6):851-5.

13. Naughton CK, Miller DC, Mager DE, Ornstein DK, Catalona WJ. A prospective randomized trial comparing 6 versus 12 prostate biopsy cores: impact on cancer detection. J Urol. 2000;164(2):388-92

14. Raaijmakers R, Kirkels WJ, Roobol MJ, Wildhagen MF, Schrder FH. Complication rates and risk factors of 5802 transrectal ultrasound-guided sextant biopsies of the prostate within a population-based screening program. Urology. 2002;60(5):826-30

15. Rietbergen JB, Kruger AE, Kranse R, Schröder FH. Complications of transrectal ultrasound-guided systematic sextant biopsies of the prostate: evaluation of complication rates and risk factors within a population-based screening program. Urology. 1997;49(6):875-80.

16. Sieber PR, Rommel FM, Agusta VE, Breslin JA, Huffnagle HW, Harpster LE. Antibiotic prophylaxis in ultrasound guided transrectal prostate biopsy. J Urol. 1997;157(6):2199-200.

17. Djavan B, Waldert M, Zlotta A, et al. Safety and morbidity of first and repeat transrectal ultrasound guided prostate needle biopsies: results of prospective European prostate cancer detection study. J Urol. 2001;166(3):856-60.
18. Deliveliotis C, John V, Louras G, et al. Multiple transrectal ultrasound guided prostatic biopsies: morbidity and tolerance. Int Urol Nephrol. 1999;31(5):681-6.

19. Fong IW, Struthers N, Honey RJ, Simbul M, Boisseau DA. A randomized comparative study of the prophylactic use of trimethoprim-sulfamethoxazole versus netilmycin-metronidazole in transrectal prostatic biopsy. J Urol. 1991;146(3):794-7.

20. Ruebush TK 2nd, McConville JH, Calia FM. A double-blind study of trimethoprim-sulfamethoxazole prophylaxis in patients having transrectal needle biopsy of the prostate. J Urol. 1979;122(4):492-4.

21. Ravery V, Billebaud T, Toublanc M, et al. Diagnostic value of ten systematic TRUS-guided prostate biopsies. Eur Urol. 1999;35(4):298-303

22. Levine MA, Ittman M, Melamed J, Lepor H. Two consecutive sets of transrectal ultrasound guided sextant biopsies of the prostate for the detection of prostate cancer. J Urol. 1998;159(2):471-5; discussion 475-6.

Sources of funding: Not declared

Conflict of interest: Not declared

Date of first submission: July 1, 2005

Last received: August 15, 2006

Accepted: August 15, 2006
AUTHOR INFORMATION

Carlos Márcio Nóbrega de Jesus, MD, PhD. Department of Urology, Faculdade de Medicina de Botucatu (Unesp), Botucatu, São Paulo, Brazil.

Luiz Antônio Corrêa, MD, PhD. Department of Urology, Faculdade de Medicina de Botucatu (Unesp), Botucatu, São Paulo, Brazil.

Carlos Roberto Padovani PhD. Department of Statistics, Bioscience Institute, Faculdade de Medicina de Botucatu (Unesp), Botucatu, São Paulo, Brazil.

Address for correspondence:

Carlos Márcio Nóbrega de Jesus

Faculdade de Medicina de Botucatu (Unesp)

Distrito de Rubião Junior, $s / n^{\circ}$

Botucatu (SP) - Brasil - CEP 18618-000

Tel. (+55 14) 3811-627

E-mail: marcio@fmb.unesp.br

\section{Complicações e riscos em biópsia guiada pelo ultra-som transretal da próstata}

CONTEXTO E OBJETIVO: A biópsia da próstata não é um procedimento isento de riscos. Existe preocupação com respeito às complicações e quais seriam os melhores antibióticos usados antes do procedimento. O objetivo foi determinar a taxa de complicações e os possíveis fatores de risco para complicação na biópsia da próstata

TIPO DE ESTUDO E LOCAL: Estudo prospectivo clínico, realizado no Hospital das Clínicas de Botucatu.

MÉTODOS: Foram realizadas biópsias em 174 pacientes que apresentavam anormalidade ao exame digital da próstata ou antígeno prostático específico maior que $4 \mathrm{ng} / \mathrm{ml}$ ou ambos. Todos os pacientes realizaram enema e antibioticoprofilaxia previamente ao exame. As complicações foram anotadas após o término do procedimento e em consultas posteriores. Algumas condições foram investigadas como possíveis fatores de risco para biópsias de próstata: idade, câncer da próstata, diabetes melito, hipertensão arterial sistêmica, antecedentes de prostatite, uso de ácido acetilsalicílico, volume prostático, número de biópsias e uso de sonda vesical.

RESULTADOS: As complicações hemorrágicas foram mais comuns $(75,3 \%)$ enquanto que as infecciosas ocorreram em $19 \%$ dos casos. O tipo mais freqüente foi a hematúria, ocorrendo em $56 \%$ dos pacientes. A infecção do trato urinário ocorreu em 16 pacientes $(9,2 \%)$. Sepse foi observada em três pacientes $(1,7 \%)$. Não houve óbitos. Em $20 \%$ dos pacientes não foram observadas complicações após o exame. A presença da sonda vesical foi fator de risco para complicações infecciosas $(p<0,05)$. O número maior de amostras nas biópsias foi relacionado à hematúria, sangramento retal e complicações infecciosas $(p<0,05)$. As demais condições investigadas não se relacionaram com complicações pós-biópsia da próstata.

CONCLUSÕES: As complicações pós-biópsia da próstata foram em sua maioria autolimitadas. A taxa de complicações graves foi baixa, sendo a biópsia de próstata guiada pelo ultra-som segura e eficaz. A retirada de um maior número de fragmentos na biópsia relaciona-se com hematúria, sangramento retal e complicações infecciosas. A sonda vesical foi um fator de risco para complicações infecciosas.

PALAVRAS-CHAVE: Biópsia por agulha. Câncer de próstata. Fatores de risco. Ultrasonografia. Próstata. 